\title{
Activation of the phosphatidylinositol-3' kinase pathway and DNA synthesis by a mutant insulin-like growth factor I receptor lacking the NPXY motif
}

\author{
K Kataoka, D Yu and M Miura \\ Molecular Diagnosis and Therapeutics, Department of Oral Restitution, Graduate School, Tokyo Medical and Dental University, 1-5-45 Yushima, Bunkyo-ku, \\ Tokyo 113-8549, Japan \\ (Requests for offprints should be addressed to M Miura; Email: masa.mdth@tmd.ac.jp)
}

\begin{abstract}
We have investigated the role of the NPXY motif in the insulin-like growth factor I receptor (IGF-IR) by focusing on the activation of the phosphatidylinositol-3' kinase (PI3-K) pathway and DNA synthesis following IGF-I stimulation. For this purpose, we established stable $\mathrm{R}$ - cell lines, which are deficient in endogenous IGF-IR, and express human IGF-IR lacking the whole NPEY ${ }^{950}$ sequence $(\triangle \mathrm{NPEY})$. The $\triangle \mathrm{NPEY}$ cells showed an apparent autophosphorylation of IGF-IR, albeit with reduced sensitivity to stimulation compared with cells expressing similar levels of wild-type IGF-IR. Activation of insulin receptor substrate (IRS)-1 and IRS-2 was severely impaired in $\triangle$ NPEY cells even at high concentrations of IGF-I. However, recruitment of p85, a regulatory subunit of PI3-K, to activated IRS-2 was similar between the cell
\end{abstract}

lines, but recruitment of p85 to IRS-1 was reduced in $\triangle$ NPEY cells. Essentially similar levels of p85- or phosphotyrosine-associated PI3-K and Akt activities were observed between the cell lines, although the sensitivity to stimulation was reduced in $\triangle \mathrm{NPEY}$ cells. Activation of extracellular signal-regulated kinase and DNA synthesis were virtually unaffected by the mutation, in terms of both sensitivity to stimulation and responsiveness. DNA synthesis was completely inhibited by the PI3-K inhibitor, LY294002. These results indicate that the IGF-IR is able to activate the PI3-K pathway and induce DNA synthesis in a normal fashion without the NPXY motif when the receptor is fully activated.

Journal of Endocrinology (2004) 181, 139-146

\section{Introduction}

Insulin-like growth factor I receptor (IGF-IR) is a transmembrane tyrosine kinase which is highly homologous to insulin receptor (IR) (Ullrich et al. 1986) and plays pivotal roles in a variety of phenotypes including development, cell growth, transformation, protection from apoptosis and differentiation (Liu et al. 1993, Beck et al. 1995, Baserga 1997, O'Connor et al. 1997). The NPEY sequence in the juxtamembrane region of IGF-IR and IR is a binding site for insulin receptor substrate (IRS)-1 and Shc which, in turn, leads to a strong activation of phosphatidylinositol-3' kinase (PI3-K) and mitogen-activated protein kinase (MAPK) respectively (Kaburagi et al. 1993, 1995, Peruzzi et al. 1999). These two major downstream pathways are responsible for the above described functions in IGF-IR (Peruzzi et al. 1999). The sequence is generally called the NPXY motif and also exists in other growth factor receptors such as IR-related protein, interleukin-4 (IL-4) receptor, and nerve growth factor (NGF) receptor (Kaburagi et al. 1995). In addition to these major pathways, IRS-2 also binds the NPXY motif, leading to the activation of the PI3-K pathway (Van Obberghen et al. 2001). Furthermore, 14-3-3 proteins bind the SSSS ${ }^{1283}$ sequence in the C-terminus of IGF-IR, which is missing in IR, and stimulate the MAPK pathway via c-Raf (Peruzzi et al. 1999, 2001).

Many studies have reported the effects of mutations of the NPXY motif in the IR on the activation of IRS-1 and Shc, or other biological responses. Mutation of tyrosine residue 960 in the NPEY ${ }^{960}$, deletion of the whole motif, or even deletions of larger portions of amino acids in proximity to the motif in the juxtamembrane region severely impairs activation of IRS-1, Shc or DNA synthesis, but not autophosphorylation of IR (Murakami \& Rosen 1991, Kaburagi et al. 1993, 1995, Chaika et al. 1997, Goalstone et al. 2001). On the other hand, similar studies on the IGF-IR are limited and have been controversial; some reports showed that mutation at tyrosine residue 950 in the NPEY ${ }^{950}$ impaired activation of autophosphorylation, IRS-1 or DNA synthesis (Craparo et al. 1995, Miura et al. 1995a), while other reports found that neither IRS-1 activation nor cell proliferation were affected by the mutation (Romano et al. 1999, Navarro \& 
Baserga 2001). The only report, to our knowledge, concerning the effects of deleting the whole NPEY sequence of the IGF-IR, showed deficient activation of autophosphorylation, IRS-1 and DNA synthesis using CHO cell lines (Hsu et al. 1994).

In this study, we attempted to clarify the role of the NPXY motif in the IGF-IR by focusing on the activation of the PI3-K pathway and DNA synthesis upon insulinlike growth factor-I (IGF-I) stimulation, which thus far has been controversial. For this purpose, we established stable $\mathrm{R}$ - cell lines, which are deficient in endogenous IGF-IR, and express human IGF-IR lacking the whole NPEY sequence $(\triangle \mathrm{NPEY})$. Activities were compared with those in cells expressing similar levels of wild-type IGF-IR after stimulation with varying concentrations of IGF-I.

\section{Materials and Methods}

\section{Materials}

Antibodies against IGF-IR $\beta$-subunits, mouse IgG conjugated with horseradish peroxidase (HRP), rabbit IgG-HRP and Protein A/G PLUS-Agarose were purchased from Santa Cruz Biotechnology (Santa Cruz, CA, USA). Anti-phosphotyrosine antibody (PY20) was purchased from Transduction Laboratory (Lexington, KY, USA). Anti-PKB/AKT pSer(473) antibody was purchased from Biosource (Camarillo, CA, USA). Anti-ACTIVE MAPK (ERK2 pThr(183)pTyr(185)) antibody and pfu polymerase were purchased from Promega (Madison, WI, USA). Anti p85 antibody was purchased from Upstate (Lake Placid, NY, USA). The ECL Western blotting analysis system and $\left[\gamma-{ }^{32} \mathrm{P}\right] \mathrm{ATP}$ were purchased from Amersham Pharmacia Biotech (Arlington Heights, IL, USA). Ready Cap was purchased from Beckmann (Fullerton, CA, USA). Recombinant human IGF-I and pCR-Blunt vector were purchased from Invitrogen (Carlsbad, CA, USA). LY294002 and PD98059 were purchased from Sigma Aldrich (St Louis, MO, USA). Phosphatidylinositol was purchased from Avanti (Alabaster, AL, USA).

\section{Plasmid construction}

The $\triangle$ NPEY mutant was derived from the human IGF-IR cDNA (Ullrich et al. 1986). For deletion of the corresponding nucleotides, PCR-assisted in vitro mutagenesis was utilized. The first PCR was performed using the primers $5^{\prime}$-GTACCGGATCGATATCCACA GCTGC and 5'-CATCAGCAGCGCTGAACACAGA GGCATAC. The latter primer was designed to lack 12 nucleotides corresponding to the NPEY ${ }^{950}$ in the IGF-IR cDNA. The second PCR was performed using the first PCR product as a $5^{\prime}$-primer and $5^{\prime}$-AAATCTTCGGCT ATGCAATTCC as a $3^{\prime}$-primer. pfu polymerase was used for both PCRs. The second PCR product was ligated to pCR-Blunt vector and the correct deletion was confirmed by a dideoxy sequencing method. The SmaI-HindIII fragment of the plasmid, including the deleted region, was used to replace the same region of the IGF-IR in pBluescript (Miura et al. 1995a). The XhoI-NotI fragment of pBPV IGF-IR (Miura et al. 1995a) was replaced by the same region of the pBluescript IGF-IR, including the deletion. The final expression plasmid was designated pBPV $\triangle$ NPEY.

\section{Cell lines and culture conditions}

$\mathrm{R}-$ cells are fibroblast cell lines derived from mouse embryos, with a targeted disruption of the IGF-IR genes (Sell et al. 1994). R - cells were co-transfected with pBPV IGF-IR or pBPV $\triangle \mathrm{NPEY}$ and pPDV6+ encoding the puromycin resistance gene (Miura et al. 1995b), by a standard calcium-phosphate precipitation method. Cells were selected in $4 \mu \mathrm{g} / \mathrm{ml}$ puromycin and the resultant clones expressing similar levels of IGF-IR were used in this study. All cell lines were maintained in growth medium as described previously (Tezuka et al. 2001). For serum-starvation, growth medium was replaced by serumfree medium containing $1 \mathrm{mg} / \mathrm{ml}$ bovine serum albumin and incubated overnight.

\section{Western blotting}

Western blotting was performed using the ECL system as described previously (Tezuka et al. 2001). Briefly, serumstarved cells were stimulated or unstimulated with IGF-I and digested in a lysis buffer $(150 \mathrm{mM} \mathrm{NaCl}, 20 \mathrm{mM}$ Tris-HCl, $\mathrm{pH} 7 \cdot 5,0 \cdot 5 \%$ Triton $\mathrm{X}-100,0 \cdot 1 \%$ SDS, $1 \mathrm{mM}$ EDTA, $100 \mathrm{mM} \mathrm{NaF}, 1 \mathrm{mM} \mathrm{NaVO}$, $1 \mathrm{mM}$ phenylmethylsulfonyl fluoride (PMSF), and $1 \mu \mathrm{g} / \mathrm{ml}$ aprotinin). Equal amounts of cell lysates were separated in SDSpolyacrylamide gel and proteins were transferred to a nitrocellulose membrane. Filters were probed with primary antibodies against target proteins and then with secondary antibodies conjugated with HRP. Proteins were visualized with the ECL system. For immunoprecipitation, cells stimulated or unstimulated with IGF-I were digested in a lysis buffer $(150 \mathrm{mM} \mathrm{NaCl}, 50 \mathrm{mM}$ Tris- $\mathrm{HCl}$, $\mathrm{pH} 7 \cdot 5,0 \cdot 25 \%$ sodium deoxycholate, $0 \cdot 1 \%$ Nonidet P-40, $100 \mu \mathrm{M} \mathrm{NaVO}_{4}, 1 \mathrm{mM} \mathrm{NaF}, 1 \mathrm{mM}$ PMSF and $1 \mu \mathrm{g} / \mathrm{ml}$ aprotinin). Cell lysates were immunoprecipitated with the indicated antibodies bound to Protein A/G Agarose. Immunoprecipitates were analyzed by Western blotting as described above. NIH image was used to quantitate intensity of bands. Results were expressed as a percentage of maximal response to IGF-I, after subtraction of values from unstimulated conditions.

Kinase assay for phosphatidylinositol-3' kinase

PI3-K assay was performed as described previously (Watanabe et al. 2002) using phosphatidylinositol and 
$\left[\gamma_{-}{ }^{32} \mathrm{P}\right] \mathrm{ATP}$ as substrates. IRS-1-, IRS-2-, p85-, or phosphotyrosine-associated PI3-K activity was determined.

\section{DNA synthesis}

Cells $\left(5 \times 10^{4}\right)$ were plated in 6-well plates and medium was changed to serum-free medium including $1 \mathrm{mg} / \mathrm{ml}$ bovine serum albumin. After incubation for $48 \mathrm{~h}$, cells were stimulated with various concentrations of IGF-I for $20 \mathrm{~h}$ and $37 \mathrm{kBq}\left[{ }^{3} \mathrm{H}\right]$ thymidine were added. Two hours after incubation, cells were extensively washed with serum-free medium and lysed with $0.5 \mathrm{M} \mathrm{NaOH}$. Cell lysates were transferred to Ready Cap and dried at $70{ }^{\circ} \mathrm{C}$ for $1 \mathrm{~h}$. Radioactivity was measured by a scintillation counter. When the PI3-K inhibitor, LY294002, or the MEK inhibitor, PD98059, was used, it was added $1 \mathrm{~h}$ prior to the addition of IGF-I.

\section{Statistical analysis}

All statistics were analyzed by Student's $t$-test or one-way ANOVA, with $P<0.05$ considered significant.

\section{Results}

Levels of wild-type (WT) and mutant IGF-IR lacking the NPEY motif, expressed in $\mathrm{R}-$ cells, are shown in Fig. 1A. Similar levels of proreceptor and IGF-IR $\beta$ subunit were expressed in WT and $\triangle \mathrm{NPEY}$ cells. No expression was detected in $\mathrm{R}-$ (puro) cells, which were transfected with a plasmid carrying the puromycin resistance gene alone. Scatchard analysis revealed that both cell lines have approximately $1 \times 10^{6}$ receptors per cell, with a $K_{\mathrm{d}}$ of $\sim 0.6 \mathrm{nM}$. Autophosphorylation of IGF-IR was monitored by Western blotting, using an antiphosphotyrosine antibody (PY20) after stimulation with varying doses of IGF-I ranging from 1 to $125 \mathrm{ng} / \mathrm{ml}$ (Fig. 1B), and its intensity was quantitated by NIH image as shown in Fig. 1C. Compared with WT cells, levels of autophosphorylation of the mutant IGF-IR were significantly lower at low IGF-I concentrations. The intensity, however, increased and reached almost comparable levels to that in WT cells at $125 \mathrm{ng} / \mathrm{ml}$ IGF-I. This was unexpected because autophosphorylation was severely impaired in $\mathrm{CHO}$ cells expressing the same mutant IGF-IR, as reported by Hsu et al. (1994).

Since autophosphorylation was induced in the mutant receptor, we examined its ability to phosphorylate IRS-1 and IRS-2. Consistent with most reports on IR with mutations in the NPXY motif (Murakami \& Rosen 1991, Kaburagi et al. 1993, 1995, Chaika et al. 1997, Goalstone et al. 2001), tyrosine phosphorylation of IRS-1 was severely impaired in cells expressing the $\triangle$ NPEY mutant (Fig. 2A). Similarly, phosphorylation of IRS-2 was also impaired in $\triangle$ NPEY cells (Fig. 2B). It should be noted that activation of IRS-1 and IRS-2 was not abrogated as shown by high doses of IGF-I. Since activated IRS-1 and IRS-2 associate with $\mathrm{p} 85$, a regulatory subunit of PI3-K, and cause PI3-K activation, the levels of $\mathrm{p} 85$ recruitment to IRS-1 and IRS-2 were examined. p85 was recruited to IRS-1 in a manner that correlated with IRS-1 activation levels in WT cells. However, p85 recruitment to IRS-1 was barely detectable in $\triangle$ NPEY cells (Fig. 2A). Interestingly, however, essentially the same levels of p 85 were recruited to IRS-2 in both cell lines even though IRS-2 activation was severely impaired in $\triangle$ NPEY cells (Fig. 2B). Quantitative analysis is shown in Fig. 2C and D.

We then tested PI3-K activity using phosphatidylinositol and $\left[\gamma_{-}{ }^{32} \mathrm{P}\right] \mathrm{ATP}$ as substrates (Fig. 3). IRS-1associated PI3-K activity was reduced in $\triangle$ NPEY cells, but to a lesser extent than the difference in IRS-1 activation. This relationship is very similar to the findings reported in a study of insulin-stimulated IR mutated at Y960 (Kaburagi et al. 1993). On the other hand, no evidence was obtained that IRS-2-associated PI3-K activity was reduced in $\triangle \mathrm{NPEY}$ cells; in fact, it was somewhat increased at high concentrations of IGF-I. In order to examine total PI3-K activity, phosphotyrosineand $\mathrm{p} 85$-associated PI3-K activities were also examined. Essentially the same activities were observed at high doses of IGF-I in both cell lines.

We next assessed activation of Akt, a downstream kinase which is activated through PI3-K and has key functions in cell survival and proliferation (Kandel \& Hay 1999). Activated PI3-K converts phosphatidylinositol 4,5-P2 to PI3,4,5-P3 and this lipid activates phosphoinositidedependent kinase (PDK), which in turn activates Akt (Kandel \& Hay 1999). Akt was activated in $\triangle$ NPEY cells, especially at high IGF-I concentrations (Fig. 4A). However, activation was significantly lower in $\triangle$ NPEY cells than in WT cells at low IGF-I concentrations (Fig. 4B). Using the same blot, activation of extracellular signalregulated kinase (ERK), a constituent of the MEK/ERK pathway, another major pathway downstream of IGF-IR, was examined. Exactly the same activation kinetics were observed in $\triangle \mathrm{NPEY}$ and WT cells (Fig. 4B), demonstrating that the MEK/ERK pathway is not affected by the mutation.

Thymidine incorporation into DNA upon IGF-I stimulation was also monitored in the two cell lines (Fig. 5A). DNA synthesis was clearly stimulated with $5 \mathrm{ng} / \mathrm{ml} \mathrm{IGF-I}$ through the mutant receptor, and there was no significant difference between the cell lines in terms of IGF-I sensitivity and maximum responsiveness. Several experiments under different conditions (such as incubation time and concentration of $\left[{ }^{3} \mathrm{H}\right]$ thymidine) showed similar results (data not shown). To examine their dependence on PI3-K activity, cells were treated with the specific PI3-K inhibitor, LY294002, before IGF-I stimulation (Fig. 5B). The inhibitor almost completely blocked IGF-I-induced 


\section{A}
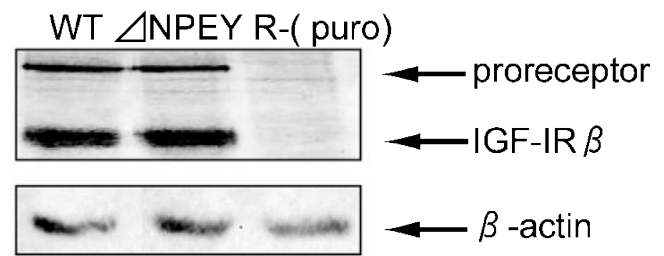

B

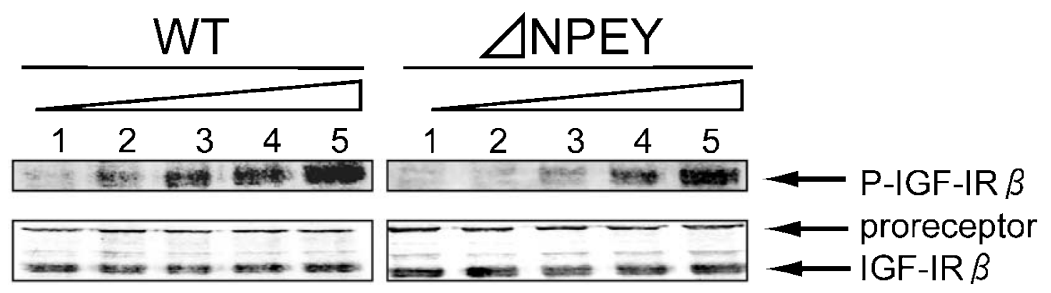

C

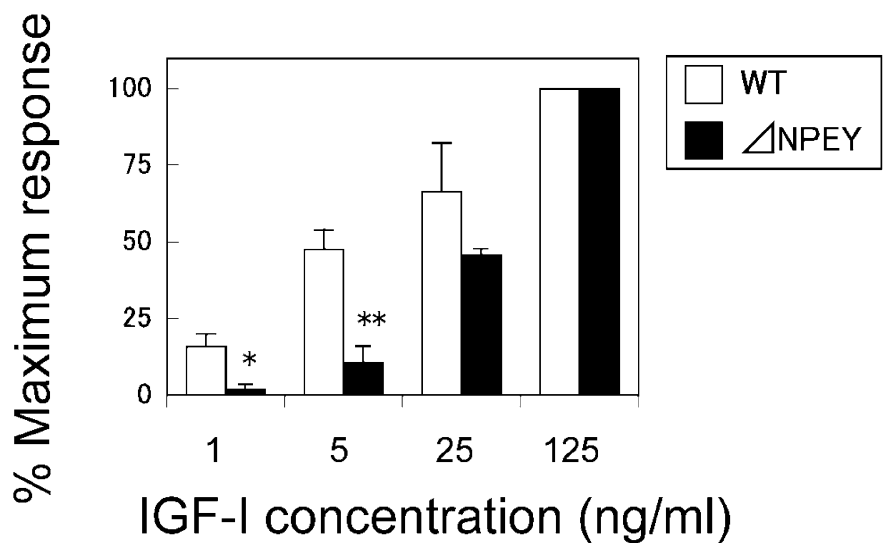

Figure 1 Expression and autophosphorylation of IGF-IR in WT and $\triangle$ NPEY cells. (A) Expression levels of IGF-IR in WT and $\triangle N P E Y$ cells. Equal amounts of cell lysates were subjected to SDS-PAGE and probed as described in Materials and Methods. $\beta$-actin was used as a loading control.

(B) Autophosphorylation of IGF-IR in WT and $\triangle$ NPEY cells in response to IGF-I. Serum-deprived cells were stimulated with a dose-range of IGF-I and cells were lysed 10 min after stimulation. Cell lysates were subjected to SDS-PAGE and probed with PY20 as described in Materials and Methods. Lane 1, 0; lane 2, $1 \mathrm{ng} / \mathrm{ml}$; lane 3, $5 \mathrm{ng} / \mathrm{ml}$; lane 4, $25 \mathrm{ng} / \mathrm{ml}$; lane 5, $125 \mathrm{ng} / \mathrm{ml} \mathrm{IGF-I.} \mathrm{(C)} \mathrm{Quantitative}$ analysis of autophosphorylation of IGF-IR in response to IGF-I. Results are expressed as a percentage of the maximal response to IGF-I and are presented as the mean \pm S.E. of three independent determinants. ${ }^{*} P<0 \cdot 02,{ }^{*} P<<0 \cdot 01$ compared with WT.

DNA synthesis, demonstrating that PI3-K activity is essential for IGF-I-induced DNA synthesis in these cell lines. Similarly, the specific MEK inhibitor, PD98059, completely blocked IGF-I-induced DNA synthesis, showing that the MEK/ERK activity is also essential in the process (data not shown).

\section{Discussion}

Our major observations using a mutant IGF-IR, which lacked the whole NPXY motif, expressed in R - cells were as follows: (1) autophosphorylation was comparable to WT cells at high concentrations of IGF-I, but was reduced at low concentrations; (2) tyrosine phosphorylation of IRS-1 and IRS-2 was impaired, even at high concentrations of IGF-I; (3) levels of p85 associated with activated IRS-1 were reduced, but levels of p 85 associated with activated IRS-2 were similar when compared with association in WT cells at high concentrations of IGF-I; (4) total PI3-K and Akt activities were essentially the same as in WT cells at high concentrations of IGF-I; and (5) DNA synthesis was induced normally in terms of both sensitivity to stimulation and responsiveness.

There are redundant pathways leading to activation of PI3-K by IR or IGF-IR, including IRS-1, IRS-2 
A

B

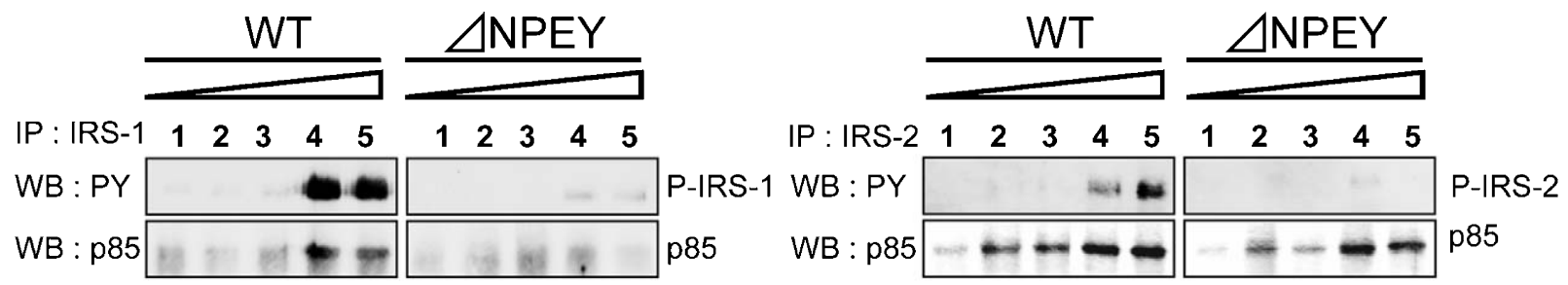

C

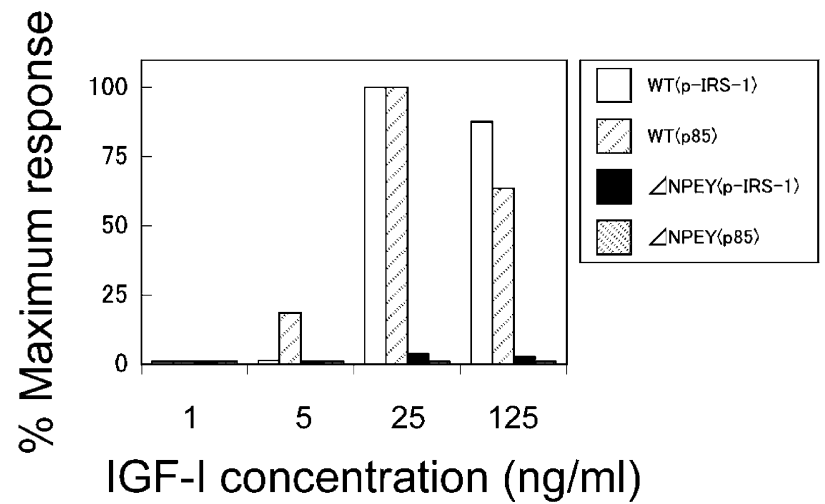

D

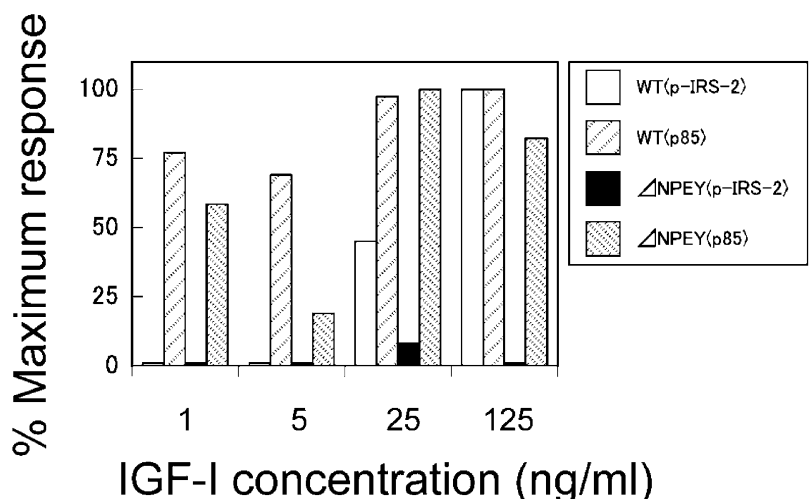

Figure 2 Activation of the PI3-K pathway in WT and $\triangle$ NPEY cells. (A and B) Tyrosine phosphorylation of IRS-1 or IRS-2 and IRS-1- or IRS-2-associated p85 in response to IGF-I. Cells stimulated or unstimulated with IGF-I were digested and cell lysates were immunoprecipitated (IP) with anti-IRS-1 or IRS-2 antibodies. Immunoprecipitates were separated in SDS-PAGE and probed with PY20 (PY) as described in Materials and Methods. The same blots were reprobed with anti-p85 antibody (p85). WB, Western blot, lane 1, 0; lane 2, $1 \mathrm{ng} / \mathrm{ml}$; lane 3, $5 \mathrm{ng} / \mathrm{ml}$; lane 4, $25 \mathrm{ng} / \mathrm{ml}$; lane 5, $125 \mathrm{ng} / \mathrm{ml} \mathrm{IGF-I.} \mathrm{(C} \mathrm{and} \mathrm{D)} \mathrm{Quantitative} \mathrm{analysis} \mathrm{of} \mathrm{tyrosine} \mathrm{phosphorylation} \mathrm{of}$ IRS-1, IRS-2, and p85 recruitment in response to IGF-I. Results are expressed as the percentage of the maximal response to IGF-I with a value from the maximal response in WT cells normalized to $100 \%$.

(Tobe et al. 1995), and the YXXM motif of the IR or the IGF-IR C-terminus, which directly activates PI3-K (Seely et al. 1995). Among the pathways, IRS-1 has been thought to be the primary molecule that stimulates PI3-K (Tobe et al. 1995). For example, IRS-1-deficient mouse embryo fibroblasts showed significantly decreased PI3-K activation and DNA synthesis upon IGF-I stimulation. Interestingly, overexpression of IRS-2 in IRS-1-deficient cells increased PI3-K activity to levels comparable with normal cells, while DNA synthesis was not increased. These results indicate that IRS-1 is a stronger contributor to PI3-K activation than IRS-2, and is essential for DNA synthesis through an unknown pathway separate from the PI3-K pathway. Furthermore, this unknown pathway cannot be activated by IRS-2 (Bruning et al. 1997). The contribution of the YXXM motif of the IGF-IR C-terminus is reported to be very low (Lamothe et al. 1995, Boehm et al. 1998). Considering these reports, our results are surprising because PI3-K activation and DNA synthesis were quite normal despite the fact that activation
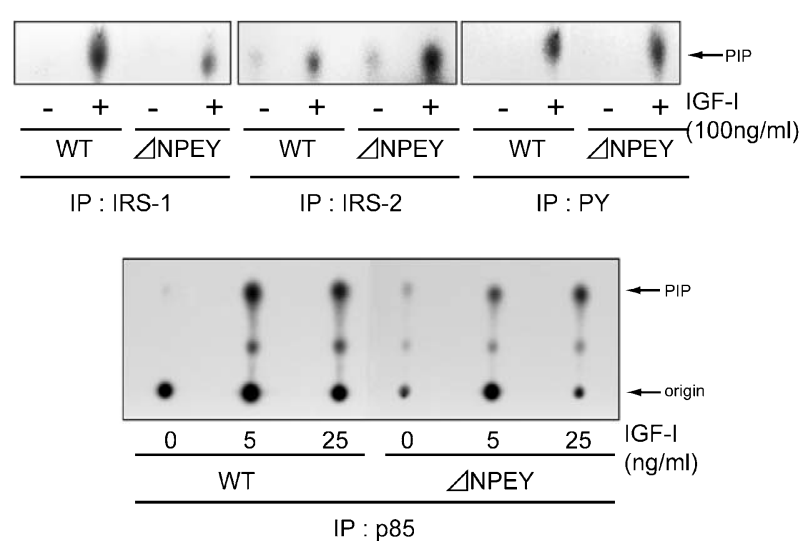

Figure 3 Activation of PI3-K in WT and $\triangle \mathrm{NPEY}$ cells.

Autoradiograms for immunoprecipitated (IP) IRS-1-, IRS-2-, phosphotyrosine (PY)-, and p85-associated PI3-K activities. PI3-K activities $10 \mathrm{~min}$ after stimulation with the indicated doses of IGF-I were measured as described in Materials and Methods. PIP, phosphatidylinositol phosphate. 
A

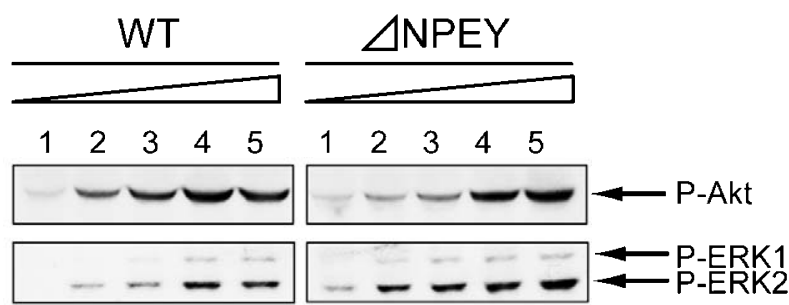

$\mathrm{B}$

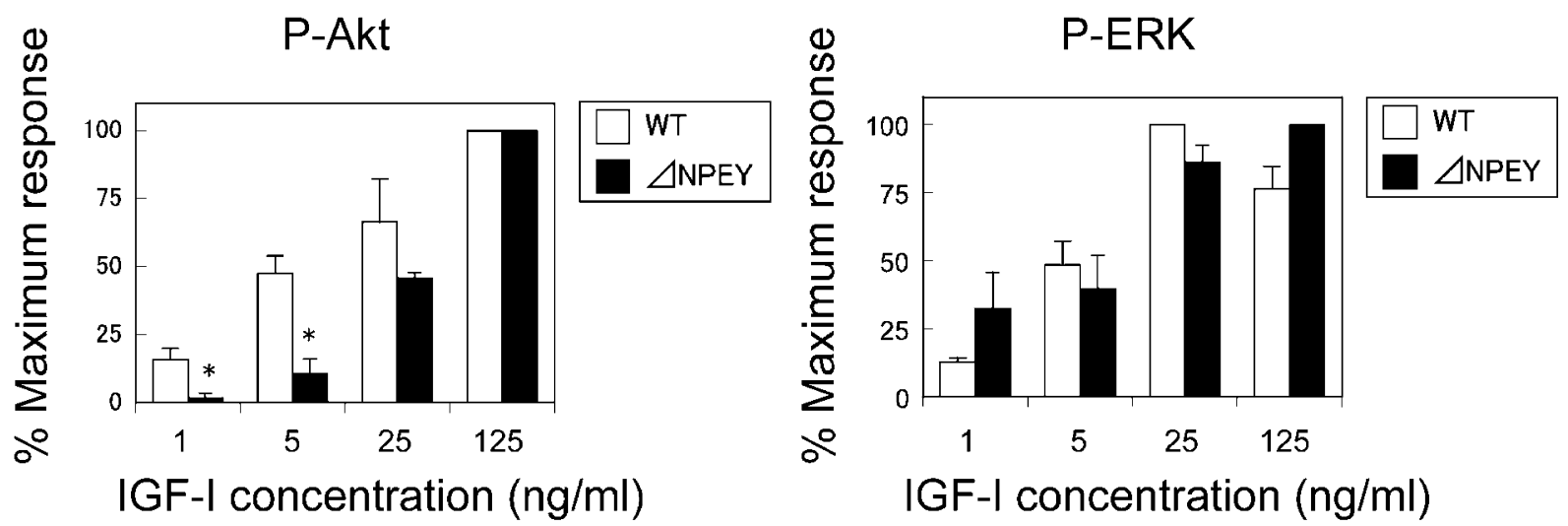

Figure 4 Akt and ERK activation in WT and $\triangle$ NPEY cells. (A) Western blots for phosphorylated Akt and ERK. Cells were stimulated with IGF-I and phosphorylated Akt and ERK were visualized as described in Materials and Methods. (B) Quantitative analysis of Akt and ERK phosphorylation in response to IGF-I. Results are expressed as the percentage of the maximal response to IGF-I and presented as the mean \pm S.E. of three independent determinants. ${ }^{*} P<0 \cdot 01$ compared with WT.

of IRS-1 and IRS-2 were severely impaired. However, our cells did retain residual IRS-1 and IRS-2 activity. These residual activities may be sufficient to lead to maximal levels of PI3-K activity, beyond which there is no further increase in kinase activity, even in WT cells where IRS-1 and IRS-2 activity is much higher. In particular, the key process was the recruitment of p 85 to activated IRS-2; similar levels of p85 associated with IRS-2 in $\triangle$ NPEY cells despite quite low levels of IRS-2 activation. Although IRS-2 is thought to be a less import-
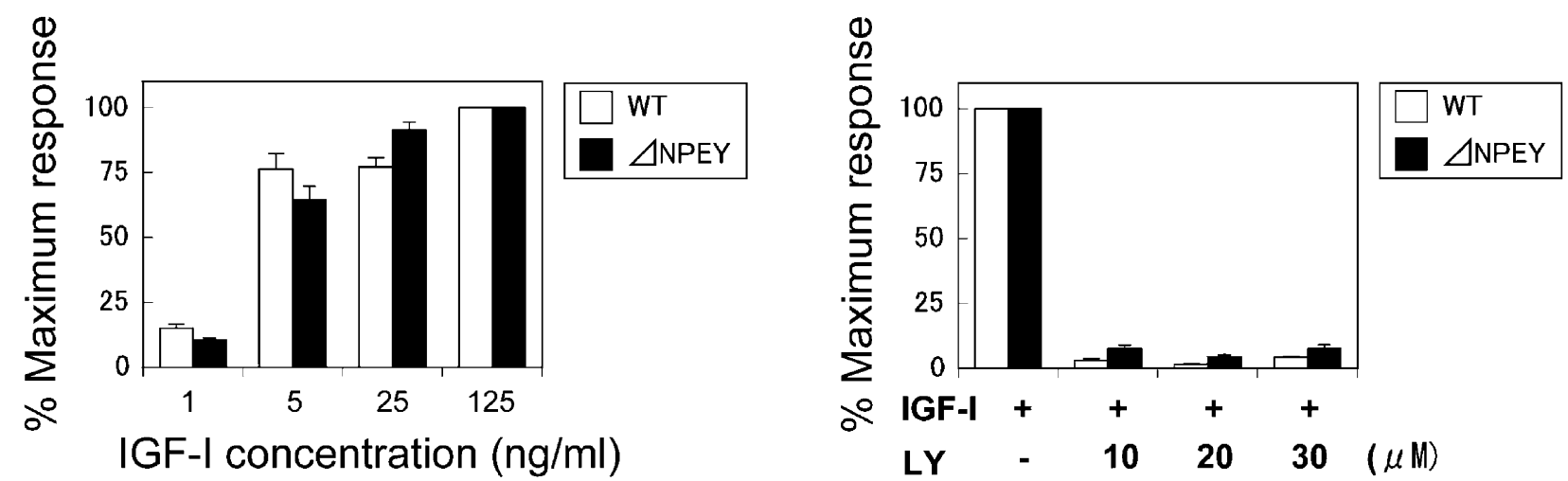

Figure 5 Stimulation of thymidine incorporation into DNA in WT and $\triangle$ NPEY cells upon IGF-I stimulation and its dependence on PI3-K activity. (A) Stimulation of DNA synthesis in the two cell lines. The results are expressed as the percentage stimulation of the maximal response to IGF-I in each cell line and presented as the mean \pm S.E. of triplicate determinants. Basal and maximally stimulated thymidine incorporation into DNA were: WT, 6206-66 953 c.p.m.; $\triangle$ NPEY, 4757-62 180 c.p.m. (B) Effects of PI3-K inhibition on IGF-I-induced DNA synthesis. Before stimulation with $25 \mathrm{ng} / \mathrm{ml}$ IGF-I, LY294002 (LY) was added at concentrations of 10, 20 or $30 \mu \mathrm{M}$ and the two cell lines were processed for DNA synthesis. 
ant contributor to PI3-K activity after IGF-I stimulation as described above, compensation by IRS-2 may contribute to obtaining normal levels of PI3-K and Akt activities in $\triangle$ NPEY cells. Finally, PI3-K-dependent DNA synthesis in the $\triangle$ NPEY cells displayed a response indistinguishable from WT cells.

Another question relates to the mechanism by which IRS- 1 and IRS-2 are phosphorylated by IGF-IR without the NPEY motif. Binding of IRS-1 to the IGF-IR requires two sites within the IGF-IR, the NPEY and tyrosine kinase domains (Tartare-Deckert et al. 1995). IRS-2 also binds the NPEY domain and the tyrosine kinase domain of IR or IGF-IR via the phosphotyrosine binding domain (PTB) and a newly identified kinase regulatory loop binding (KRLB) domain respectively. Binding of the IRS-2 molecule to the IR mutated at Y960 is reduced by approximately half and binding of IRS-2 to the IGF-IR mutated at Y950 is abrogated in a yeast two-hybrid assay (Sawka-Verhelle et al. 1996, Van Obberghen et al. 2001). Residual levels of IRS-1 and IRS-2 phosphorylation, which presumably arise through the tyrosine kinase domain of IGF-IR alone, may contribute to activation of the PI3-K pathway and DNA synthesis in mammalian cells, even though mutation at Y950 is enough to abrogate binding in a yeast two-hybrid assay.

Activation of the MEK/ERK pathway is also important for DNA synthesis. As a matter of fact, ERK activation was completely retained in cells expressing the mutant receptor and was essential for DNA synthesis. The MEK/ERK pathway is activated through two different regions in the IGF-IR: the NPXY motif and the SSSS ${ }^{1283}$ motif in the C-terminus. The reports that either region is sufficient to induce full activation of the pathway support our results (Dews et al. 2000, Morrione et al. 2001, Navarro \& Basevga 2001).

The characteristics of the IGF-IR lacking the NPXY motif, as described in this study, may account for the discordant reports concerning the NPEY mutant. As long as the mutant receptor retains residual ability to phosphorylate IRS-1 and IRS-2, relative expression levels of the mutant IGF-IR and IRS-1 or IRS-2 may affect the extent of their phosphorylation. In fact, IR with a mutation at Y960, which has a severely impaired ability to phosphorylate IRS-1, is able to phosphorylate IRS-1 when IRS-1 is overexpressed (Chen et al. 1995). Therefore, the results of some studies may have been influenced by the IGF-I concentrations used and the levels of IGF-IR, IRS-1 and IRS-2 expression. Two reports demonstrated that IGF-I-induced DNA synthesis and cell proliferation were severely decreased by the mutation. Expression of the mutant IGF-IR was at a level of $\sim 1 \times 10^{5}$ receptors per cell in the reports. This low level of expression resulted in seemingly impaired autophosphorylation of IGF-IR (Hsu et al. 1994, Miura et al. 1995a), as predicted from our results where the level of autophosphorylation showed reduced sensitivity to stimulation in mutant cells (Fig. 1). Therefore, insufficient activation of IRS-1 or IRS-2 because of impaired receptor tyrosine kinase activity may lead to a failure of DNA synthesis.

In conclusion, we have demonstrated that the NPXY motif in the IGF-IR is not essential for activation of the PI3-K pathway or DNA synthesis. These two activities, however, are probably dependent on residual IRS-1 and IRS-2 stimulation presumably brought about through the tyrosine kinase domain of the receptor. IGF-I concentrations and expression levels of mutant IGF-IR and IRS-1 or IRS-2 in cells could therefore influence downstream signaling events.

\section{Acknowledgements}

We thank Dr M Yanagishita and Dr I Morita for discussion.

\section{Funding}

This study was partly supported by Grants-in-Aid for Scientific Research on Priority Areas (13218045) (M M) from the Ministry of Education, Culture, Sports, Science, and Technology of Japan.

\section{References}

Baserga R 1997 The price of independence. Experimental Cell Research 236 1-3.

Beck KD, Powell-Braxton L, Widmer HR, Valverde J \& Hefti F 1995 IGF1 gene disruption results in reduced brain size, CNS hypomyelination, and loss of hippocampal granule and striatal parvalbumin-containing neurons. Neuron 14 717-730.

Boehm JE, Chaika OV \& Lewis RE 1998 Anti-apoptotic signaling by a colony-stimulating factor-1 receptor/insulin receptor chimera with a juxtamembrane deletion. Journal of Biological Chemistry 273 $7169-7176$.

Bruning JC, Winnay J, Cheatham B \& Kahn R 1997 Differential signaling by insulin receptor substrate 1 (IRS-1) and IRS-2 in IRS-1-deficient cells. Molecular and Cellular Biology 17 1513-1521.

Chaika OV, Chaika N, Volle DJ, Wilden PA, Pirrucello SJ \& Lewis RE 1997 CSF-1 receptor/insulin receptor chimera permits CSF-1-dependent differentiation of 3T3-L1 preadipocytes. Journal of Biological Chemistry 272 11968-11974.

Chen D, Van Horn DJ, White MF \& Backer JM 1995 Insulin receptor substrate 1 rescues insulin action in $\mathrm{CHO}$ cells expressing mutant insulin receptors that lack a juxtamembrane NPXY motif. Molecular and Cellular Biology 15 4711-4717.

Craparo A, O'Neill TJ \& Gustafson TA 1995 Non-SH2 domains within insulin receptor substrate-1 and SHC mediate their phosphotyrosine-dependent interaction with the NPEY motif of the insulin-like growth factor I receptor. Journal of Biological Chemistry 270 15639-15643.

Dews M, Prisco M, Peruzzi F, Romano G, Morrione A \& Baserga R 2000 Domains of the insulin-like growth factor I receptor required for the activation of extracellular signal-regulated kinases. Endocrinology 141 1289-1300. 
Goalstone ML, Leiner JW, Berhanu P, Sharma PM, Olefsky JM \& Draznin B 2001 Insulin signals to prenyltransferases via the Shc branch of intracellular signaling. Journal of Biological Chemistry 276 12805-12812.

Hsu D, Knudson PE, Zapf A, Rolband GC \& Olefsky JM 1994 NPXY motif in the insulin-like growth factor-I receptor is required for efficient ligand-mediated receptor internalization and biological signaling. Endocrinology 134 744-750.

Kaburagi Y, Momomura K, Yamamoto-Honda R, Tobe K, Tamori Y, Sakura H, Akanuma Y, Yazaki Y \& Kadowaki T 1993 Site-directed mutagenesis of the juxtamembrane domain of the human insulin receptor. Journal of Biological Chemistry 268 16610-16622.

Kaburagi Y, Yamamoto-Honda R, Tobe K, Ueki K, Yachi M, Akanuma Y, Stephens RM, Kaplan D, Yazaki Y \& Kadowaki T 1995 The role of the NPXY motif in the insulin receptor in tyrosine phosphorylation of insulin substrate-1 and Shc. Endocrinology 136 3437-3443.

Kandel ES \& Hay N 1999 The regulation and activities of the multifunctional serine/threonine kinase Akt/PKB. Experimental Cell Research 253 210-219.

Lamothe B, Bucchini D, Jami J \& Joshi RL 1995 Interaction of p85 subunit of PI 3-kinase with insulin and IGF-1 receptors analysed by using the two-hybrid system. FEBS Letter 373 51-55.

Liu J-P, Baker J, Perkins AS, Robertson EJ \& Efstratiadis A 1993 Mice carrying null mutations of the genes encoding insulin-like growth factor I (igf-1) and type 1 IGF receptor (igf1r). Cell 75 $59-72$.

Miura M, Li S \& Baserga R 1995a Effect of a mutation at tyrosine 950 of the insulin-like growth factor I receptor on the growth and transformation of cells. Cancer Research 55 663-667.

Miura M, Surmacz E, Burgaud JL \& Baserga R 19956 Different effects on mitogenesis and transformation of a mutation at tyrosine ${ }^{125}$ I of the insulin-like growth factor I receptor. Journal of Biological Chemistry $27022639-22644$.

Morrione A, Navarro M, Romano G, Dews M, Reiss K, Valentinis B, Belletti B \& Baserga R 2001 The role of the insulin receptor substrate-1 in the differentiation of rat hippocampal neuronal cells. Oncogene 20 4842-4852.

Murakami MS \& Rosen OM 1991 The role of insulin receptor autophosphorylation in signal transduction. Journal of Biological Chemistry 266 22653-22660.

Navarro M \& Baserga R 2001 Limited redundancy of survival signals from the type 1 insulin-like growth factor receptor. Endocrinology 142 1073-1081.

O'Connor R, Kauffmann-Zeh A, Liu Y, Lehar S, Evan GI, Baserga R \& Blattler WA 1997 Identification of domains of the insulin-like growth factor I receptor that are required for protection from apoptosis. Molecular and Cellular Biology 17 427-435.

Peruzzi F, Prisco M, Dews M, Salomoni P, Grassilli E, Romano G, Calabretta B \& Baserga R 1999 Multiple signaling pathways of the insulin-like growth factor 1 receptor in protection from apoptosis. Molecular and Cellular Biology 19 7203-7215.

Peruzzi F, Prisco M, Morrione A, Valentinis B \& Baserga R 2001 Anti-apoptotic signaling of the insulin-like growth factor-I receptor through mitochondrial translocation of c-Raf and Nedd4. Journal of Biological Chemistry 276 25990-25996.
Romano G, Prisco M, Zanocco-Marani T, Peruzzi F, Valentinis B \& Baserga R 1999 Dissociation between resistance to apoptosis and the transformed phenotype in IGF-I receptor signaling. Journal of Cellular Biochemistry 72 294-310.

Sawka-Verhelle D, Tartare-Deckert S, White MS \& Van Obberghen E 1996 Insulin-receptor substrate-2 binds to the insulin receptor through its phosphotyrosine binding domain and through a newly identified domain comprising amino acids 591-786. Journal of Biological Chemistry 271 5980-5983.

Seely BL, Reichart DR, Staubs PA, Jhun BH, Hsu D, Maegawa H, Milarski KL, Saltiel AR \& Olefsky JM 1995 Localization of the insulin-like growth factor I receptor binding sites for the SH2 domain proteins $\mathrm{p} 85$, Syp and GTPase activating protein. Journal of Biological Chemistry 270 19151-19157.

Sell C, Dumenil G, Deveaud C, Miura M, Coppola D, DeAngelis T, Rubin R, Efstratiadis A \& Baserga R 1994 Effect of a null mutation of the insulin-like growth factor I receptor gene on growth and transformation of mouse embryo fibroblasts. Molecular and Cellular Biology 14 3604-3612.

Tartare-Deckert S, Sawka-Verhelle D, Murdaca J \& Van Obberghen E 1995 Evidence for a differential interaction of SHC and the insulin receptor substrate-1 (IRS-1) with the insulin-like growth factor-I (IGF-I) receptor in the yeast two-hybrid system. Journal of Biological Chemistry 270 23456-23460.

Tezuka M, Watanabe H, Nakamura S, Yu D, Aung W, Sasaki T, Shibuya H \& Miura M 2001 Antiapoptotic activity is dispensable for insulin-like growth factor I receptor-mediated clonogenic radioresistance after $\gamma$-irradiation. Clinical Cancer Research 7 3206-3214.

Tobe K, Tamemoto H, Yamauchi T, Aizawa S, Yazaki Y \& Kadowaki T 1995 Identification of a $190-\mathrm{kD}$ a protein as a novel substrate for the insulin receptor kinase functionally similar to insulin receptor substrate-1. Journal of Biological Chemistry $\mathbf{2 7 0}$ 5698-5701.

Ullrich A, Gray A, Tam AW, Yang-Feng T, Tsubokawa M, Collins C, Henzel W, le Bon T, Kahuria S, Chen E, Jakobs S, Francke U, Ramachandran J \& Fujita-Yamaguchi Y 1986 Insulin-like growth factor I receptor primary structure: comparison with insulin receptor suggests structural determinants that define functional specificity. EMBO Journal 5 2503-2512.

Van Obberghen E, Baron V, Deiahaye L, Emanuelli B, Filippa N, Giorgetti-Peraldi S, Lebrun P, Mothe-Satney I, Peraldi P, Rocchi S, Sawka-Verhelle D, Tartare-Deckert S \& Giudicelli J 2001 Surfing the insulin signaling web. European Journal of Clinical Investigation 31 966-977.

Watanabe H, Yu D, Sasaki T, Shibuya H, Hosoi Y, Asada M, Komatsu K \& Miura M 2002 Insulin-like growth factor I receptor is expressed at normal levels in Nijmegen breakage syndrome cells. Biochemical and Biophysical Research Communications 296 62-66.

Received in final form 5 December 2003

Accepted 24 December 2003

Made available online as an

Accepted Preprint 12 January 2004 